\title{
Sequencing analysis of the ghrelin receptor (growth hormone secretagogue receptor type 1a) gene
}

\author{
Johanna Vartiainen, Seppo M Pöykkö, Tuija Räisänen, Y Antero Kesäniemi and Olavi Ukkola \\ Department of Internal Medicine and Biocenter Oulu, University of Oulu, PO Box 5000, 90014 Oulu, Finland \\ (Correspondence should be addressed to J Vartiainen; Email: rvartiai@mail.student.oulu.fi)
}

\begin{abstract}
Objectives and design: Ghrelin is a novel 28 amino acid peptide which is reported to have several endocrine and non-endocrine actions. It possesses strong growth hormone (GH)-releasing activity, which is mediated via the GH secretagogue receptor type 1a (GHS-R1a). We hypothesised that there might be functional sequential variations in the GHS-R1a gene affecting phenotypes linked to the GH/insulin-like growth factor-I (IGF-I)-axis.

Methods: To test our hypothesis we chose patients from our OPERA (Oulu Project Elucidating Risk of Atherosclerosis) study with low $(n=96)$ and high $(n=96)$ IGF-I levels, sequenced their GHS-R1a gene exons and performed association studies.

Results: We found five single-nucleotide polymorphisms (SNPs) which did not change the amino acid sequence. We were unable to detect associations between the SNPs and the IGF-I plasma concentrations, but instead we showed that SNP $171 \mathrm{C}>\mathrm{T}$ was associated with the values of the area under the insulin curve (AUCIN) in an oral glucose tolerance test and with IGF-binding protein-1 (IGFBP-1) concentrations $(P<0.05)$. SNP 477G $>$ A was associated with the low density lipoprotein and very low density lipoprotein cholesterol plasma levels and AUCIN values $(P<0.05)$.

Conclusions: This study was the first genomic screening of the GHS-R1a gene in a population. It suggests that genetic variations in the GHS-R1a gene are not the main regulators of IGF-I levels. However, the variants may be associated with IGFBP-1 concentrations and insulin metabolism.
\end{abstract}

European Journal of Endocrinology $150457-463$

\section{Introduction}

Ghrelin is a novel 28 amino acid peptide hormone which was originally extracted from rat stomach (1) and which has subsequently been shown to be expressed at lower levels in the hypothalamus and pituitary and also in several peripheral tissues (2). Ghrelin at pharmacological doses strongly stimulates growth hormone $(\mathrm{GH})$ release in rodents and humans $(1,3)$ acting synergistically with growth hormone-releasing hormone (GHRH) (4). Ghrelin is also adipogenic in rodents (5) and has orexigenic potency both in animals and in humans $(6,7)$. However, ghrelin is downregulated in human obesity (8). Ghrelin has been proposed to act as a link between the regulation of energy balance and GH secretion (9).

Ghrelin is an endogenous ligand for the type 1a growth hormone secretagogue receptor (GHS-R1a). GHS-R1a binds acylated ghrelin and other growth hormone secretagogues and mediates their stimulating activity on GH secretion $(1,10)$. This receptor is a member of the G-protein-coupled receptor superfamily and it was first detected from the hypothalamus, pituitary and arcuate nucleus, where it is concentrated (10). It is also expressed at lower levels in the thyroid gland, pancreas, spleen, myocardium and adrenal glands (2), which supports the notion that, in addition to stimulating $\mathrm{GH}$ release, ghrelin also participates in other biological functions.

The biological activities of $\mathrm{GH}$ are mediated through insulin-like growth factor-I (IGF-I) and GH is characterised as the major driving force of IGF-I synthesis. IGF-I is produced mainly in the liver and released into the bloodstream, where it circulates as a free molecule or is bound to the IGF-binding protein (IGFBP) (11). Six different IGFBPs have been described (12), of which IGFBP-1 seems to affect IGF-I bioactivity effectively by regulating the amount of free IGF-I in the circulation. Decreased portal levels of insulin lead to elevated levels of IGFBP-1 which, in turn, reduces free IGF-I and diminishes the negative feedback on GH release in somatotrophs (13). The effects of ghrelin on the GH/IGF-I axis are not completely clear. Obesity is characterised by decreased ghrelin levels (8) and $\mathrm{GH}$ deficiency, while IGF-I levels are within the normal range or even elevated (14). Decreased IGF-I levels 
have been associated with type 2 diabetes (15), diabetes-related complications and heart diseases $(16,17)$. Anorectic patients have elevated ghrelin (18) and IGFBP-1 levels but subnormal free IGF-I levels, while their $\mathrm{GH}$ levels are within the normal range (19). There is evidence that the role of ghrelin in physiology may be sexually dimorphic; decreased expression levels of the ghrelin receptor GHS-R1a gene in transgenic mice result in decreased GH and IGF-I levels more often in female than in male mice (20). This also suggests that a connection between GHS-R 1a and IGF-I levels might exist. However, sequential variations in the GHS-R1a gene have not been described previously in a population-based study. We therefore screened the region of the GHS-R1a gene encoding the entire protein product to find sequence variations that might have an effect on protein structure and function and might be related to different phenotypes in the GH/IGF-I axis, e.g. IGF-I plasma levels.

\section{Subjects and methods}

\section{Subjects}

The subjects were chosen from our OPERA (Oulu Project Elucidating Risk of Atherosclerosis) study, which is an epidemiological case-control study addressing the risk factors and disease end-points of atherosclerotic cardiovascular diseases. The series was collected during 1991-1993 at the Department of Internal Medicine of the University of Oulu. This study has been described in more detail elsewhere $(21,22)$. The subjects for this study were selected from the hypertensive cohort, which consisted of 600 age-stratified Finnish subjects (300 men and 300 women). Fasting blood samples were collected, and the oral glucose tolerance tests (OGTTs) were performed (with $75 \mathrm{~g}$ glucose) at the Department of Internal Medicine of the University of Oulu. Intima-media thicknesses (IMTs) were measured from the common carotid arteries by ultrasonography. The routine clinical laboratory tests were carried out in the Central Laboratory of Oulu University Hospital. Subsequently, several parameters have been measured using fasting plasma samples and the genomic DNA extracted from them. Measurements of the total IGF-I and IGFBP-1 concentrations were carried out using commercial kits (DSL-10-2800 ACTIVE Non Extraction IGF-I ELISA, Diagnostic Systems Laboratories, Inc., Webster, TX, USA and IGFBP-1 IOMA test, Oy Medix Biochemica Ab, Kauniainen, Finland). Ghrelin concentrations were assessed (23) by radioimmunoassay (RIA) using a commercial kit (Peptide Radioimmuno Assay Kit, Phoenix Pharmaceuticals, Inc., Belmont, CA, USA). Fasting insulin levels were measured by twosite immunoenzymometric assay (AIA-PACK IRI, Tosoh Corp., Tokyo, Japan), and fasting glucose levels were determined by the glucose dehydrogenase method (Diagnostica, Merck, Darmstadt, Germany).
Quantitative insulin sensitivity check indexes (QUICKI) were calculated as described elsewhere (24). The measurements of plasma triglyceride concentrations and very-low-density lipoprotein (VLDL), high-density lipoprotein (HDL) and low-density lipoprotein (LDL) cholesterol levels have been described in detail elsewhere (25). All the subjects volunteered for the study, which was approved by the Ethical Committee of the University of Oulu. The study was conducted according to the principles of the Declaration of Helsinki 1975, as revised in 2000.

Since we were also interested in studying the association of sequential variations with some diabetes-related parameters, we chose subjects from the hypertensive group of the OPERA study, which includes more diabetics than the control group. Another reason for choosing the study subjects from the hypertensive cohort was that our earlier results suggested that the effect of low ghrelin on blood pressure levels was stronger in a hypertensive state. When the hypertensive and non-hypertensive study cohorts were analysed separately, the association between ghrelin and blood pressure levels remained only in the hypertensive cohort (23). Therefore, ghrelin and its receptor as well as their genetic variation might play a specific role in hypertension.

Subjects with high $(n=96)$ and low $(n=96)$ total IGF-I plasma concentrations were chosen. The number of patients with type 2 diabetes was 11 in the group with high IGF-I levels and 16 in the group with low levels $(P=0.299)$. Both groups were sexstratified, consisting of 48 men and 48 women. Physiological age-dependent reduction in IGF-I levels was taken into account by stratifying both of the study groups for age: the average age (mean) in the group with high IGF-I levels was 51.1 years and that in the group with low levels was 51.7 years. In the group with high IGF-I levels the mean concentration of IGF-I was $136.5 \mathrm{ng} / \mathrm{ml} \quad(95 \%$ confidence interval $(C I)=127.4-145.5)$ and that of IGFBP-1 was $2.9 \mathrm{ng} / \mathrm{ml} \quad(95 \% \quad \mathrm{CI}=2.4-3.4)$. The mean IGF-I concentration in the group of low IGF-I levels was $30.2 \mathrm{ng} / \mathrm{ml}(95 \% \mathrm{CI}=27.0-33.4)$, and the mean IGFBP-1 concentration was $3.9 \mathrm{ng} / \mathrm{ml}(95 \% \mathrm{CI}=2.5-$ 5.3). The difference in the IGFBP-1 levels between the groups with high and low IGF-I levels was not statistically significant $(P=0.517)$.

\section{Amplification of genomic DNA by PCR and sequencing of amplified DNA}

Two overlapping fragments covering the first exon and one fragment covering the second exon of the GHS-R 1a gene were amplified from genomic DNA by PCR using DyNAzyme II DNA polymerase (Finnzymes, Espoo, Finland) or AmpliTaq Gold (PE Applied Biosystems, Foster City, CA, USA) enzymes. The primers, (Sigma-Genosys Ltd., The Woodlands, TX, 
Table 1 Primers and annealing temperatures used in PCR amplification. Sequencing was performed using the same primers.

\begin{tabular}{|c|c|c|c|c|c|}
\hline Fragment & Forward primer & Reverse primer & Annealing temperature & Number of cycles & Product size (bp) \\
\hline 1 & $5^{\prime}$ ctccetacgcgtctgcac $3^{\prime}$ & $5^{\prime}$ ggaagcagatggcgaagtag $3^{\prime}$ & $56^{\circ} \mathrm{C}$ & 35 & 569 \\
\hline 2 & $5^{\prime}$ cagtgaqaqctgcacctacg $3^{\prime}$ & $5^{\prime}$ agaaggcacagggagaggat $3^{\prime}$ & $58^{\circ} \mathrm{C}$ & 30 & 491 \\
\hline 3 & $5^{\prime}$ ttgctgtgcatttcttgagc $3^{\prime}$ & $5^{\prime}$ cttcctcccaagttctgctg $3^{\prime}$ & $56^{\circ} \mathrm{C}$ & 30 & 430 \\
\hline
\end{tabular}

Fragment 1 was amplified using AmpliTaq Gold DNA polymerase (PE Applied Biosystems) and the other fragments were amplified using DyNAzyme (Finnyzmes).

USA), fragment sizes, annealing temperatures and the number of cycles for each fragment are shown in Table 1 . The PCR products were purified with calf intestinal phosphatase, (CIP; Finnzymes) and Exonuclease I (New England BioLabs Inc., Beverly, MA, USA) and sequenced in both directions using a DYEnamic ET Terminator Cycle Sequencing kit (Amersham Biosciences, Bucks, UK). Detection of sequences was carried out with an ABI 377 sequencer (PE Applied Biosystems).

\section{Association studies and statistical analysis}

Statistical analysis was performed using the SPSS statistical package (versions 9.0 and 11.5; SPSS Inc., Chicago, IL, USA). The frequencies of the observed single-nucleotide polymorphisms (SNPs) were compared in the groups with low and high IGF-I plasma levels by a chi-square test. The associations of the observed SNPs with the body mass indexes (BMIs), IMTs and metabolic parameters were studied by using one-way analysis of variance (ANOVA), Mann-Whitney's U-test, $t$-test and analysis of covariance (ANCOVA) when appropriate. Appropriate transformations were used to meet the criteria of the parametric tests. Significance was considered at $P<0.05$.

\section{Results}

\section{Sequence analysis of the GHS-R1a gene exons}

Cycle sequencing of genomic DNA revealed five SNPs in the first exon and none in the second exon of the GHS$\mathrm{R} 1 \mathrm{a}$ gene. The found mutations were $\mathrm{C}$ to $\mathrm{T}$ at nucleotide $60(60 \mathrm{C}>\mathrm{T})$, (nucleotide number 1 corresponds to the first nucleotide of the first codon), $\mathrm{C}$ to $\mathrm{T}$ at nucleotide 171 (171C $>\mathrm{T}), \mathrm{C}$ to $\mathrm{G}$ at nucleotide 447 $(447 \mathrm{C}>\mathrm{G}), \mathrm{G}$ to $\mathrm{A}$ at nucleotide $477(477 \mathrm{G}>\mathrm{A})$ and $\mathrm{C}$ to $\mathrm{A}$ at nucleotide $531(531 \mathrm{C}>\mathrm{A})$. The location of the SNPs is illustrated in Fig. 1 (adapted from the original paper (26)), and the genotype and allele frequencies are presented in Table 2. All of the SNPs have been entered into the GenBank previously and the access numbers are indicated in Table 2. None of these mutations changes the coded amino acid. The distribution patterns were in agreement with HardyWeinberg equilibrium.

\section{Association studies}

The frequencies of the discovered SNPs were compared between the groups with high and low IGF-I levels by a chi-square test. The allele frequencies were equally distributed between the groups (data not shown). However, SNP $171 \mathrm{C}>\mathrm{T}$ was associated with the IGFBP-1 and area under the insulin curve (AUCIN) values, showing statistical significance in ANOVA $(P=0.009$ and $P=0.020$ respectively; Table 3$)$. When adjustments for age, BMI and sex were carried out, significance was maintained (ANCOVA, $P=0.038$ and $P=0.038$ respectively; Table 3 ). The wild-type $\mathrm{C} / \mathrm{C}$ homozygotes had the highest AUCIN values and the lowest IGFBP-1 plasma levels compared with the heterozygotes or variant homozygotes. The differences were statistically significant between the wild-type homozygotes and heterozygotes in pair-wise comparisons (AUCIN: $P=0.011$ and $P=0.032$ after Bonferroni correction; IGFBP-1: $P=0.012$ and $P=0.037$ after Bonferroni correction; Table 3).

SNP $477 \mathrm{G}>\mathrm{A}$ was associated with the AUCIN values. There was a significant difference in the AUCIN values between the $477 \mathrm{G}>\mathrm{A}$ genotypes (ANOVA, $P=0.007$, Table 3). Significance was maintained

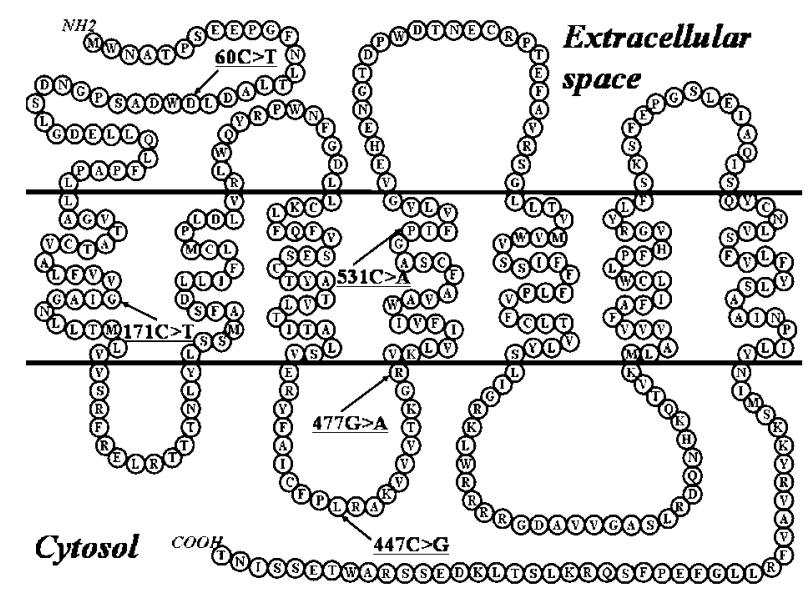

Figure 1 Genomic screening for sequence variations in the type 1a growth hormone secretagogue receptor (GHS-R1a) gene revealed five single-nucleotide polymorphisms (SNPs). The SNPs were found in the codons of amino acids, which are indicated by arrows in this presentation of the predicted structure of the receptor. The structure of the receptor was illustrated by adapting the information from the original paper (26). 
Table 2 Genotype and allele frequencies for the sequence variations observed in the study.

\begin{tabular}{lcccccc}
\hline & & \multicolumn{3}{c}{$\begin{array}{c}\text { Genotype } \\
\text { frequency }(n)\end{array}$} & $\begin{array}{c}\text { Allele } \\
\text { frequency } \\
(\%)\end{array}$ \\
\hline $60 \mathrm{C}>\mathrm{T}$ & $\mathrm{rs} 2232165$ & $\mathrm{C} / \mathrm{C}$ & $\mathrm{C} / \mathrm{T}$ & $\mathrm{T} / \mathrm{T}$ & $\mathrm{C}$ & $\mathrm{T}$ \\
& & 189 & 3 & - & 99.2 & 0.8 \\
$171 \mathrm{C}>\mathrm{T}$ & $\mathrm{rs} 495225$ & $\mathrm{C} / \mathrm{C}$ & $\mathrm{C} / \mathrm{T}$ & $\mathrm{T} / \mathrm{T}$ & $\mathrm{C}$ & $\mathrm{T}$ \\
& & 20 & 81 & 91 & 31.5 & 68.5 \\
$447 \mathrm{C}>\mathrm{G}$ & $\mathrm{rs} 2232169$ & $\mathrm{C} / \mathrm{C}$ & $\mathrm{C} / \mathrm{G}$ & $\mathrm{G} / \mathrm{G}$ & $\mathrm{C}$ & $\mathrm{G}$ \\
& & 189 & 3 & - & 99.2 & 0.8 \\
$477 \mathrm{G}>\mathrm{A}$ & $\mathrm{rs572169}$ & $\mathrm{G} / \mathrm{G}$ & $\mathrm{G} / \mathrm{A}$ & $\mathrm{A} / \mathrm{A}$ & $\mathrm{G}$ & $\mathrm{A}$ \\
& & 81 & 85 & 26 & 64.3 & 35.7 \\
$531 \mathrm{C}>\mathrm{A}$ & $\mathrm{rs} 4988509$ & $\mathrm{C} / \mathrm{C}$ & $\mathrm{C} / \mathrm{A}$ & $\mathrm{A} / \mathrm{A}$ & $\mathrm{C}$ & $\mathrm{A}$ \\
& & 188 & 4 & - & 99.0 & 1.0 \\
\hline
\end{tabular}

The nomenclature of the SNPS shows the bases taking part in nucleotide substitutions and the numbers stand for the nucleotides at which the substitutions have taken place; number one corresponds to the first nucleotide of the first codon. The GenBank access number for the SNPs are shown in the column entitled dbSNP rs\#.

after adjustments for age, sex and BMI (ANCOVA, $P=0.049$ ). In the pairwise comparisons, the difference was significant between the wild-type G/G homozygotes and $\mathrm{G} / \mathrm{A}$ heterozygotes $(P=0.014, P=0.042$ after Bonferroni correction; Table 3). The wild-type homozygotes had the highest AUCIN values.

SNP $477 \mathrm{G}>\mathrm{A}$ was also associated with the plasma concentrations of VLDL and HDL cholesterol. There were significant differences in the VLDL and HDL cholesterol levels between the genotypes (ANOVA, $P=0.021$ and $P=0.032$ respectively; Table 3$)$. After adjustment for age, BMI, sex and alcohol consumption, the statistical difference in the HDL concentrations was of borderline significance (ANCOVA, $P=0.05$ ) and the difference in the pairwise comparisons was significant between the variant homozygotes and heterozygotes $(P=0.021$, Table 3$)$. HDL cholesterol plasma concentrations were the lowest among the variant homozygotes. However, statistical significance disappeared when Bonferroni correction was performed $(P=0.064$; Table 3$)$. The statistical significance of the VLDL association disappeared after adjustments for age, sex and BMI (ANCOVA, $P=0.071$; Table 3).

Association studies were also performed for SNPs and BMI, plasma ghrelin and fasting insulin concentrations, QUICKI, triglyceride, LDL cholesterol plasma concentrations and carotid intima-media thicknesses. None of the SNPs showed statistically significant associations with any of these parameters. SNPs $60 \mathrm{C}>\mathrm{T}$, $447 \mathrm{C}>\mathrm{G}$ and $531 \mathrm{C}>\mathrm{A}$ were not associated with any parameters studied.

\section{Discussion}

The GH/IGF-I axis has an important role in normal growth and metabolism. A GH pulse in the circulation has been thought to be the major driving force for IGF-I synthesis and secretion. Some association studies between ghrelin, an endogenous ligand for the $\mathrm{GH}$ secretagogue receptor, and IGF-I levels exist. In a recent study, serum IGF-I levels were not altered by ghrelin administration (27). Fasting, which is characterised by increased ghrelin secretion, has been shown to lead to a decrease in IGF-I levels (28).

Table $3 \mathrm{BMI}$ and metabolic parameters in relation to GHS-R1a $171 \mathrm{C}>\mathrm{T}$ and $477 \mathrm{G}>\mathrm{A}$. SNPs in the study group consisting of 96 male and 96 female hypertensive patients. The values are shown as means $(95 \% \mathrm{Cl})$.

\begin{tabular}{|c|c|c|c|c|c|c|c|c|}
\hline & \multicolumn{4}{|c|}{$171 \mathrm{C}>\mathrm{T}$} & \multicolumn{4}{|c|}{$477 G>A$} \\
\hline & $\mathrm{C} / \mathrm{C}(n=20)$ & $\mathrm{C} / \mathrm{T}(n=81)$ & $\mathrm{T} / \mathrm{T}(n=91)$ & $P$ & $\mathrm{G} / \mathrm{G}(n=81)$ & $\mathrm{G} / \mathrm{A}(n=85)$ & $\mathrm{A} / \mathrm{A}(n=26)$ & $P$ \\
\hline BMI $\left(\mathrm{kg} / \mathrm{m}^{2}\right)$ & $\begin{array}{l}29.6 \\
(27.8-31.4)\end{array}$ & $\begin{array}{l}28.4 \\
(27.4-29.5)\end{array}$ & $\begin{array}{l}29.0 \\
(28.1-30.0)\end{array}$ & ns & $\begin{array}{l}29.5 \\
(28.6-30.4)\end{array}$ & $\begin{array}{l}28.1 \\
(27.1-29.1)\end{array}$ & $\begin{array}{l}29.2 \\
(26.9-31.4)\end{array}$ & ns \\
\hline Fasting insulin (mU/l) & $\begin{array}{l}20.1 \\
(13.8-26.7)\end{array}$ & $\begin{array}{l}17.4 \\
(14.1-20.8)\end{array}$ & $\begin{array}{l}15.7 \\
(13.7-17.7)\end{array}$ & ns & $\begin{array}{l}17.9 \\
(15.1-20.8)\end{array}$ & $\begin{array}{l}15.9 \\
(13.2-18.7)\end{array}$ & $\begin{array}{l}16.6 \\
(12.0-21.3)\end{array}$ & ns \\
\hline IGF-I (mmol/l) & $\begin{array}{l}100.7 \\
(66.1-135.3)\end{array}$ & $\begin{array}{l}89.4 \\
(75.4-103.4)\end{array}$ & $\begin{array}{l}74.3 \\
(62.0-86.6)\end{array}$ & ns & $\begin{array}{l}84.0 \\
(69.3-98.7)\end{array}$ & $\begin{array}{l}86.4 \\
(72.7-100.1)\end{array}$ & $\begin{array}{l}71.8 \\
(52.4-91.1)\end{array}$ & ns \\
\hline Ghrelin (mmol/l) & $\begin{array}{l}201.0 \\
(161.8-240.3)\end{array}$ & $\begin{array}{l}198.9 \\
(181.9-215.8)\end{array}$ & $\begin{array}{l}213.7 \\
(197.7-229.7)\end{array}$ & ns & $\begin{array}{l}204.6 \\
(187.0-222.3)\end{array}$ & $\begin{array}{l}207.2 \\
(190.9-223.5)\end{array}$ & $\begin{array}{l}207.2 \\
(175.5-238.9)\end{array}$ & ns \\
\hline AUCIN (mmol/h) & $\begin{array}{l}247.1 \\
(133.4-360.7)\end{array}$ & $\begin{array}{l}148.0 \\
(123.4-172.7)\end{array}$ & $\begin{array}{l}164.5 \\
(141.2-187.8)\end{array}$ & $\begin{array}{l}0.020^{a} \\
0.038^{b, d}\end{array}$ & $\begin{array}{l}192.6 \\
(157.7-227.6)\end{array}$ & $\begin{array}{l}136.5 \\
(116.2-156.9)\end{array}$ & $\begin{array}{l}177.7 \\
(123.8-231.5)\end{array}$ & $\begin{array}{l}0.007^{a} \\
0.049^{b, f}\end{array}$ \\
\hline IGFBP-1 (ng/ml) & $\begin{array}{l}1.9 \\
(1.3-2.5)\end{array}$ & $\begin{array}{l}4.3 \\
(2.7-5.8)\end{array}$ & $\begin{array}{l}3.0 \\
(2.4-3.5)\end{array}$ & $\begin{array}{l}0.009^{a} \\
0.038^{b, e}\end{array}$ & $\begin{array}{l}3.7 \\
(2.1-5.3)\end{array}$ & $\begin{array}{l}3.0 \\
(2.5-3.5)\end{array}$ & $\begin{array}{l}3.6 \\
(2.0-5.1)\end{array}$ & ns \\
\hline VLDL-chol (mmol/l) & $\begin{array}{l}0.62 \\
(0.48-0.77)\end{array}$ & $\begin{array}{l}0.53 \\
(0.43-0.63)\end{array}$ & $\begin{array}{l}0.56 \\
(0.47-0.65)\end{array}$ & ns & $\begin{array}{l}0.62 \\
(0.51-0.72)\end{array}$ & $\begin{array}{l}0.47 \\
(0.39-0.55)\end{array}$ & $\begin{array}{l}0.63 \\
(0.45-0.80)\end{array}$ & $\begin{array}{l}0.021^{a} \\
0.071^{b}\end{array}$ \\
\hline HDL-chol (mmol/l) & $\begin{array}{l}1.32 \\
(1.14-1.15)\end{array}$ & $\begin{array}{l}1.28 \\
(1.20-1.37)\end{array}$ & $\begin{array}{l}1.29 \\
(1.22-1.37)\end{array}$ & ns & $\begin{array}{l}1.25 \\
(1.17-1.33)\end{array}$ & $\begin{array}{l}1.36 \\
(1.28-1.45)\end{array}$ & $\begin{array}{l}1.18 \\
(1.24-1.34)\end{array}$ & $\begin{array}{l}0.032^{a} \\
0.050^{c, g}\end{array}$ \\
\hline
\end{tabular}

chol, cholesterol.

${ }^{a}$ One-way ANOVA, no adjustments. ${ }^{b}$ Adjusted for age, sex and BMI in ANCOVA. ${ }^{c}$ Adjusted for age, sex, BMI and alcohol consumption in ANCOVA. In pairwise comparisons the difference occurs: ${ }^{d}$ between $\mathrm{C} / \mathrm{C}$ and $\mathrm{C} / \mathrm{T}$ genotypes $\left(P=0.011\right.$ and $P=0.032$ with Bonferroni correction), ${ }^{e}$ between $\mathrm{C} / \mathrm{C}$ and $\mathrm{C} / \mathrm{T}$ genotypes $\left(P=0.012\right.$ and $P=0.037$ with Bonferroni correction), ${ }^{t}$ between $\mathrm{G} / \mathrm{G}$ and $\mathrm{G} / \mathrm{A}$ genotypes $(P=0.014$ and $P=0.042$ with Bonferroni correction and ${ }^{g}$ between $\mathrm{G} / \mathrm{A}$ and $\mathrm{A} / \mathrm{A}$ genotypes $(P=0.021$ and $P=$ not significant (ns) after Bonferroni correction). 
Considering the role of ghrelin in hyposomatotrophism of human obesity, no causative relationship could be demonstrated in a recent study (29). This and other earlier observations provide evidence that the effects of ghrelin on GH secretion and energy homeostasis may be distinct. Our results suggest that the five ghrelin receptor polymorphisms found in this study have no evident association with IGF-I levels. However, two SNPs were found to be associated with glucose metabolism-related parameters: AUCIN values and IGFBP-1 plasma levels.

Insulin is a powerful downregulator of IGFBP-1 synthesis, and IGFBP-1 levels have been shown to be elevated in type 1 diabetes (30). However, the situation in type 2 diabetes and insulin resistance may be different. The increased AUCIN values observed in the $171 \mathrm{C} / \mathrm{C}$ subjects in the current study indicate impairment of insulin action, although the GHS-R 1a $171 \mathrm{C}>\mathrm{T}$ polymorphism was not associated with any other insulin metabolism parameters. Low IGFBP-1 levels have been associated with obesity and with cardiovascular risk factors in insulin resistance syndromes (31). The latter association is in accordance with our observations in the present study, where $171 \mathrm{C} / \mathrm{C}$ homozygotes showed both high AUCIN values and low IGFBP-1 levels. These subjects may, therefore, have the lowest insulin sensitivity for an unknown reason. One hypothesis could be that the different expression levels of GHS-R1a might have an effect on the regulation of insulin metabolism by affecting ghrelin signalling. For example, the SNP $171 \mathrm{C}>\mathrm{T}$ could be in linkage disequilibrium with a mutation that is able to alter the level of ghrelin receptor expression. A mutation of this kind could be present in, for example, promoter or intron areas that were not screened in this study. Another theory could be that SNP might be able to change a binding site for transcription factors and, in this way, may also lead to altered expression levels of the protein product. There is evidence that decreased expression levels of GHS$\mathrm{R} 1 \mathrm{a}$ lead to decreased GH and IGF-I values in transgenic female mice (20); however, the relationship between altered GHS-R1a expression levels and IGFBP-1 levels has yet to be elucidated.

The role of ghrelin in insulin secretion is controversial as ghrelin has been shown both to lower (32) and to raise (33) insulin levels. Insulin has been shown to downregulate IGFBP-1 synthesis and, probably for this reason, IGFBP-1 levels are altered in different nutritional states (34). These acute and long-term states of malnutrition are also characterised by elevated ghrelin levels $(18,28)$. These findings together with our results raise a question: is it possible that ghrelin levels might play a role in the regulation of IGFBP-1 levels?

Considering the results of SNP 477G > A, significant differences were seen only between heterozygotes and either wild-type or variant homozygotes. Heterozygotes had lower VLDL cholesterol levels and higher HDL cholesterol levels than did the variant 477A/A homozygotes. This result could be interpreted to indicate that heterozygosity at this nucleotide is beneficial in terms of the VLDL/HDL ratio. Anyhow, the statistical significance was lost when some adjustments were made, which further suggests that this polymorphism does not play an independent role in plasma lipid metabolism. The heterozygotes had significantly lower AUCIN values than did the wild-type $477 \mathrm{G} / \mathrm{G}$ homozygotes. However, no significant associations of this SNP with IGFBP-1 were observed.

The three other polymorphisms were not associated with any of the parameters studied, a result which was predictable due to their low allele frequencies. Actually, in our population, SNPs $60 \mathrm{C}>\mathrm{T}$ and $447 \mathrm{C}>\mathrm{G}$ have too low an allelic frequency (allelic frequency $<1 \%$ ) to fulfil the criteria for polymorphism.

It must be mentioned that, in theory, there is always a risk for false positive signals when sequencing PCR products. We increased the reliability of the method by sequencing the exons in both directions. Also, the detected SNPs were not located close to the primers. Therefore, our genotyping results can be regarded as being quite reliable. Another thing that must be remembered is that the sample size for each genotype is not very large in any of our five SNPs. If we had analysed a larger number of subjects, the differences would probably have been clearer. However, our results provide useful information for the genes and pathways that should be studied further.

It is important to point out that the role of endogenous ghrelin in the regulation of GH secretion in a physiological situation is unknown, and that the ghrelin/GHS-R1a interaction at the molecular level has not yet been fully clarified. GHS-R1a has been demonstrated to be a highly conserved gene throughout evolution (35), and no mutations with an effect on the protein structure have been described. It is likely that this receptor has an essential or even vital function in organisms, and our result of no amino acid-changing mutations in 192 patients is therefore not very surprising.

In conclusion, our study was the first to describe a genomic screening of the GHS-R1a gene in a population. We found five SNPs, but no amino acid-changing mutations in the protein-coding area. The SNPs were not associated with IGF-I levels. Instead, SNP $171 \mathrm{C}>\mathrm{T}$ was associated with IGFBP-1 levels and AUCIN values and SNP $477 \mathrm{G}>\mathrm{A}$ was associated with AUCIN values and VLDL and HDL levels. The data suggest that genetic variations in the protein coding area of the ghrelin receptor GHS-R1a gene are not the main regulators of IGF-I levels. However, the variants may be associated with the regulation of insulin metabolism and IGFBP-1 levels. 


\section{Acknowledgements}

This study was supported by the Research Council for Health of the Academy of Finland and the Finnish Foundation for Cardiovascular Research. Sakari Kakko MD, PhD, and laboratory technicians Heidi Häikiö and Marja-Leena Kytökangas at the Department of Internal Medicine at the University of Oulu are gratefully thanked for providing assistance with some of the experiments.

\section{References}

1 Kojima M, Hosoda H, Date Y, Nakazato M, Matsuo H \& Kangawa $\mathrm{K}$. Ghrelin is a growth-hormone-releasing acylated peptide from stomach. Nature $1999 \mathbf{4 0 2} 656-660$.

2 Gnanapavan S, Kola B, Bustin SA, Morris DG, McGee P, Fairclough $\mathrm{P}$ et al. The tissue distribution of the mRNA of ghrelin and subtypes of its receptor, GHS-R, in humans. Journal of Clinical Endocrinology and Metabolism 200286 1169-1174.

3 Arvat E, Di Vito L, Broglio F, Papotti M, Muccioli G, Dieguez C et al. Preliminary evidence that ghrelin, the natural GH secretagogue (GHS)-receptor ligand, strongly stimulates GH secretion in humans. Journal of Endocrinological Investigation 200023 493-495.

4 Hataya Y, Akamizu T, Takaya K, Kanamoto N, Ariyasu H, Saijo M et al. A low dose of ghrelin stimulates growth hormone $(\mathrm{GH})$ release synergistically with $\mathrm{GH}$ releasing hormone in humans. Journal of Clinical Endocrinology and Metabolism $2001 \mathbf{8 6}$ $4552-4555$.

5 Tschöp M, Simley DL \& Helman ML. Ghrelin induces adiposity in rodents. Nature $2000 \mathbf{4 0} 7908-7913$.

6 Nagaya N, Kojima M, Uematsu M, Yamagishi M, Hosoda H, Oya H et al. Hemodynamic and hormonal effects of human ghrelin in healthy volunteers. American Journal of Physiology - Regulatory Integrative and Comparative Physiology 2001280 R1483-R1487.

7 Nakazato M, Murakami N, Date Y, Kojima M, Matsuo H, Kangawa $\mathrm{K}$ et al. A role for ghrelin in the central regulation of feeding. Nature 2001409 194-198.

8 Shiiya T, Nakazato M, Mizuta M, Date Y, Mondal MS, Tanaka M et al. Plasma ghrelin levels in lean and obese humans and the effect of glucose on ghrelin secretion. Journal of Clinical Endocrinology and Metabolism 200287 240-244.

9 Ukkola $\mathrm{O} \&$ Pöykkö S. Ghrelin growth and obesity. Annals of Medicine 200234 102-108.

10 Howard AD, Feighner SD, Cully DF, Arena JP, Liberator PA, Rosenblum CI et al. A receptor in pituitary and hypothalamus that functions in growth hormone release. Science 1996273 974-977.

11 Baxter RC. The insulin-like growth factors and their binding proteins. Comparative Biochemistry and Physiology 1988 B91 229-235.

12 Hwa V, Oh Y \& Rosenfeld RG. The insulin-like growth factor-binding protein (IGFBP) superfamily. Endocrine Reviews $199920761-787$.

13 Orskov H. Somatostatin, growth hormone, insulin-like growth factor-I, and diabetes: friends or foes? Metabolism $1996 \mathbf{4 5}$ (8 suppl 1) 91-95.

14 Maccario M, Tassone F, Grottoli S, Rossetto R, Gauna C \& Ghigo E. Neuroendocrine and metabolic determinants of the adaptation of GH/IGF-I axis to obesity. Annales d'Endocrinologie 200263 $140-144$.

15 Tan K \& Baxter RC. Serum insulin like growth factor I levels in adult diabetic patients: the effect of age. Journal of Clinical Endocrinology and Metabolism $1986 \mathbf{6 3} 651-655$.

16 Spallarossa P, Brunelli C, Minuto F, Caruso D, Battistini M, Caponnetto $\mathrm{S}$ et al. Insulin-like growth factor-I and angiographically documented coronary artery disease. American Journal of Cardiology 199677 200-202.

17 Janssen JA, Jacobs ML, Derkx FH, Weber RF, van der Lely AJ \& Lamberts SW. Free and total insulin-like growth factor I (IGF-I), IGF-binding protein-1 (IGFBP-1) and IGFBP-3 and their relationships to the presence of diabetic retinopathy and glomerular hyperfiltration in insulin-dependent diabetes mellitus. Journal of Clinical Endocrinology and Metabolism 199782 2809-2815.

18 Otto B, Cuntz U, Fruehauf E, Wawarta R, Folwaczny C, Riepl RL et al. Weight gain decreases elevated plasma ghrelin concentrations of patients with anorexia nervosa. European Journal of Endocrinology 2001145 669-673.

19 Argente J, Caballo N, Barrios V, Munoz MT, Pozo J, Chowen JA et al. Multiple endocrine abnormalities of the growth hormone and insulin-like growth factor axis in patients with anorexia nervosa: effect of short- and long-term weight recuperation. Journal of Clinical Endocrinology and Metabolism 199782 2084-2092.

20 Shuto Y, Shibasaki T, Otagiri A, Kuriyama H, Ohata H, Tamura H et al. Hypothalamic growth hormone secretagogue receptor regulates growth hormone secretion, feeding, and adiposity. Journal of Clinical Investigation 2002109 1429-1436.

21 Kiema TR, Kauma H, Rantala AO, Lilja M, Reunanen A, Kesäniemi YA et al. Variation at the angiotensin-converting enzyme gene and angiotensinogen gene loci in relation to blood pressure. Hypertension $1996 \mathbf{2 8} 1070-1075$.

22 Rantala AO, Kauma H, Lilja M, Savolainen MJ, Reunanen A \& Kesäniemi YA. Prevalence of the metabolic syndrome in drugtreated hypertensive patients and control subjects. Journal of Internal Medicine 1999245 163-174.

23 Pöykkö S, Kellokoski E, Hörkkö S, Kauma H, Kesäniemi YA \& Ukkola O. Low plasma ghrelin is associated with insulin resistance, hypertension, and an increased risk for type 2 diabetes. Diabetes 200352 2546-2553.

24 Katz A, Nambi SS, Mather K, Baron AD, Follmann DA, Sullivan G et al. Quantitative insulin sensitivity check index: a simple, accurate method for assessing insulin sensitivity in humans. Journal of Clinical Endocrinology and Metabolism 200085 2402-2410.

25 Kauma H, Savolainen MJ, Heikkila R, Rantala AO, Lilja M, Reunanen A et al. Sex difference in the regulation of plasma high density lipoprotein cholesterol by genetic and environmental factors. Human Genetics 199697 156-162.

26 Feighner SD, Howard AD, Prendergast K, Palyha OC, Hreniuk DL, Nargund R et al. Structural requirements for the activation of the human growth hormone secretagogue receptor by peptide and nonpeptide secretagogues. Molecular Endocrinology 199812 $137-145$.

27 Okumura H, Nagaya N, Enomoto M, Nakagawa E, Oya H \& Kangawa K. Vasodilatory effect of ghrelin, an endogenous peptide from the stomach. Journal of Cardiovascular Pharmacology 2002 $39779-783$.

28 Muller AF, Lamberts SW, Janssen JA, Hofland LJ, Koetsveld PV, Bidlingmaier $\mathrm{M}$ et al. Ghrelin drives $\mathrm{GH}$ secretion during fasting in man. European Journal of Endocrinology $2002 \mathbf{1 4 6}$ 203-207.

29 Lindeman JH, Pijl H, Van Dielen FM, Lentjes EG, Van Leuven C \& Kooistra T. Ghrelin and the hyposomatotropism of obesity. Obesity Research $2002101161-1166$.

30 Frystyk J, Skjaerbaek C, Vestbo E, Fisker S \& Orskov H. Circulating levels of free insulin-like growth factors in obese subjects: the impact of type 2 diabetes. Diabetes/Metabolism Research Reviews $199915314-322$.

31 Lee PD, Giudice LC, Conover CA \& Powell DR. Insulin-like growth factor binding protein-1: recent findings and new directions. Proceedings of the Society for Experimental Biology and Medicine $1997216319-357$.

32 Broglio F, Arvat E, Benso A, Gottero C, Muccioli G \& Papotti M. Ghrelin, a natural GH secretagogue produced by the stomach, induces hyperglycemia and reduces insulin secretion in humans. Journal of Clinical Endocrinology and Metabolism 2001 86 5083-5086. 
33 Date Y, Nakazato M, Hashiguchi S, Dezaki K, Mondal MS, Hosoda $\mathrm{H}$ et al. Ghrelin is present in pancreatic alpha-cells of humans and rats and stimulates insulin secretion. Diabetes 200251 124-129.

34 Frystyk J, Grofte T, Skjaerbaek C \& Orskov H. The effect of oral glucose on serum free insulin-like growth factor-I and -II in healthy adults. Journal of Clinical Endocrinology and Metabolism 199782 3124-3127.

35 Palyha OC, Feighner SD, Tan CP, McKee KK, Hreniuk DL, Gao YD et al. Ligand activation domain of human orphan growth hormone (GH) receptor secretagogue receptor (GHS-R) conserved

from pufferfish to humans. Molecular Endocrinology $2000 \mathbf{1 4}$ 160-169.

Received 15 September 2003

Accepted 15 December 2003 